\title{
Ultramafic Lamprophyre from the Wajrakarur Kimberlite Field of Southern India and it's Petrogenetic Significance
}

\author{
Ashish Dongre ${ }^{1}$, Fanus Viljoen ${ }^{2}$, M. Malandkar ${ }^{3}$ and Petrus Le Roux ${ }^{4}$ \\ ${ }^{1}$ Department of Geology, Savitribai Phule Pune University, Pune 411007, India \\ ${ }^{2}$ Department of Geology, University of Johannesburg, Auckland Park 2006, South Africa \\ ${ }^{3}$ Department of Geology, Institute of Science, Aurangabad 431004, India \\ ${ }^{4}$ Department of Geology, University of Cape Town, Rondebosch 7700, India
}

\section{Introduction}

Wajrakarur kimberlite field (WKF) of southern India contains more than 45 intrusions of diamond host rocks. They have been identified as kimberlites, orangeites/ olivine lamproites and ultramafic lamprophyres during previous studies. All the so far reported kimberlites and related rocks show $\sim 1100$ Ma age except Timmasamudram kimberlite which gave $\sim 90$ Ma age (e.g. Chalapathi Rao et al., 2013; Chalapathi Rao et al., 2016).

Present detailed study from one of the pipe of Lattavaram cluster of WKF utilizes mineralogical genetic, radiogenic isotopic composition and whole rock geochemical approach on one of the previously known kimberlite pipe to shows its affinity towards ultramafic lamprophyre (UML) and to further discuss the genetic and geodynamic significance. The rock contains abundant elongated crystals of clinopyroxene in groundmass, olivine phenocrysts that are mostly serpentinised, microphenocrysts of phlogopite restricted to groundmass, and amphiboles, spinels and carbonates. However the additional presence of Ti-rich garnets (Schorlomite) in groundmass mineralogically confirms it to be aillikite (e.g. Tappe et al., 2005). It is considered that the present aillikite also belongs to the Mesoproterozoic (i.e. $1100 \mathrm{Ma}$ ) age spectrum of kimberlite and related rocks of WKF.

\section{Constituent mineral compositions}

Microphenocrysts of phlogopite are widespread in the present pipe that coexists with clinopyroxenes and schorlomites in groundmass. In phlogopites Ti content are high and ranging from 3.9 to $6.4 \mathrm{wt} . \%$ $\mathrm{TiO}_{2}$ whereas $\mathrm{Al}_{2} \mathrm{O}_{3}$ shows constant range varying between 9-11 wt.\%. High $\mathrm{BaO}$ content is up to 4.4 wt. $\%$ and correlates positively with $\mathrm{Al}_{2} \mathrm{O}_{3}$. The fluorine content is also high having concentrations up to $3.05 \mathrm{wt} \%$. These phlogopites differ from kimberlite and orangeites in terms of $\mathrm{Al}$ and $\mathrm{Ti}$ enrcihment and coexists with other aluminous phases in groundmass.

Clinopyroxne occurs only in groundmass and present in two paragenesis, one as elongate crystals of less than $40 \mu$ at the base of serpentine and another as subhedral resorbed crystals associated with amphiboles. They mostly shows diopside composition rich in $\mathrm{CaO}$ (18.8 to 23.48 wt.\%) and $\mathrm{MgO}$ (15.17 to 16.98 wt.\%) and poor in $\mathrm{FeO}$ (3.87 to 7.9 wt.\%). Diopsides here shows $\mathrm{Al}$ and Ti enriched trend typical of ultramafic lamprophyres. Atomic $\mathrm{Al} / \mathrm{Ti}$ ratios is $\sim 2$ similar to aillikite clinopyroxenes from type area of Aillik Bay, Greenland (Tappe et al., 2008). Groundmass clinopyroxenes from recently reported Timmasamudram kimberlite of WKF (e.g. Dongre et al., 2017) are also plotted for comparison that are mostly showing composition similar to worldwide orangeite and lamproite and indicates a different composition.

Amphiboles are free from inclusion and any zoning and occur as subhedral grains at the margins of olivine crystals and also as discrete grains in groundmass. All the amphiboles are ranging in composition from potassium richterite to titanian potassium richterite having $\mathrm{TiO}_{2}$ content 2 to 4 wt.\%. They show higher and approximately constant $\mathrm{Na} / \mathrm{K}$ ratio with varying $\mathrm{Ti}$ and composition away from the MARID field and similar to Torngat and Aillik Bay UMLs (e.g. Tappe et al., 2006) 
and are unlike of amphiboles from lamproites and orangeites. The $\mathrm{Al}_{2} \mathrm{O}_{3}$ content varies up to $1.2 \mathrm{wt} . \%$ and crystals typically co-exists in groundmass with other aluminous phases such as clinopyroxene, phlogopite and schorlomite.

$\mathrm{Cr}_{2} \mathrm{O}_{3}$ content in groundmass spinels reaches up to 46 wt. $\%$ and $\mathrm{Al}_{2} \mathrm{O}_{3}$ is mostly below 5 wt.\%. Spinels rich in Cr, Al mostly follow the titanomagnetite trend ie. trend 2 (Mitchell, 1986) whereas rim composition rich in $\mathrm{Mg}$ (up to $16.7 \mathrm{wt} . \% \mathrm{MgO}$ ) and poor in $\mathrm{Cr}$, $\mathrm{Al}$ follows magnesian ulvöspinel compositional trend.

\section{Geochemistry and conclusion}

The rock shows ultramafic nature with $\mathrm{SiO}_{2}$ depletion (41-43 wt.\%) and $\mathrm{MgO}$ enrichment ( 19 wt.\%). All samples have high incompatible element abundances when normalized to primitive mantle values (Sun and McDonough, 1995) and show very low HREE contents i.e. 1 x PM for Lu as well as fractionated LREE/HREE contents $\left(\mathrm{La} / \mathrm{Yb}_{\mathrm{n}}\right.$ is ranging from 40-98). They show major depletions at $\mathrm{K}$, $\mathrm{Sr}$, Hf and $\mathrm{Ti}$ which are the characteristic of aillikites worldwide. Depletions at $\mathrm{K}$ in aillikites are relatively smaller when compared to kimberlites.

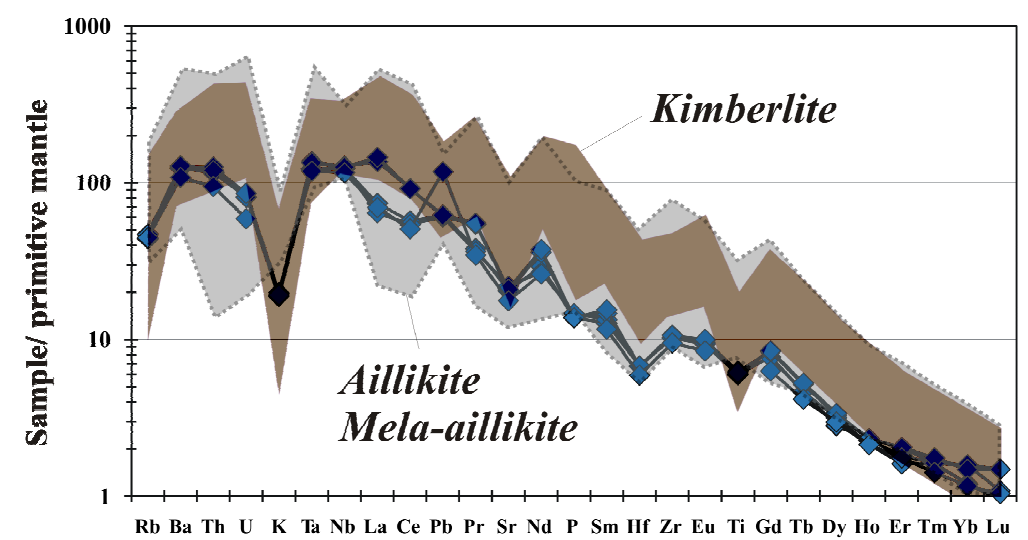

Figure 1: Primitive mantle normalized multielement diagram for samples under study. Field for aillikite and mela-aillikite composition is based on data from Tappe et al. (2006, 2008) and Donnelly et al. (2011), and for kimberlited is from Becker and Le Roex (2006) given for comparison.

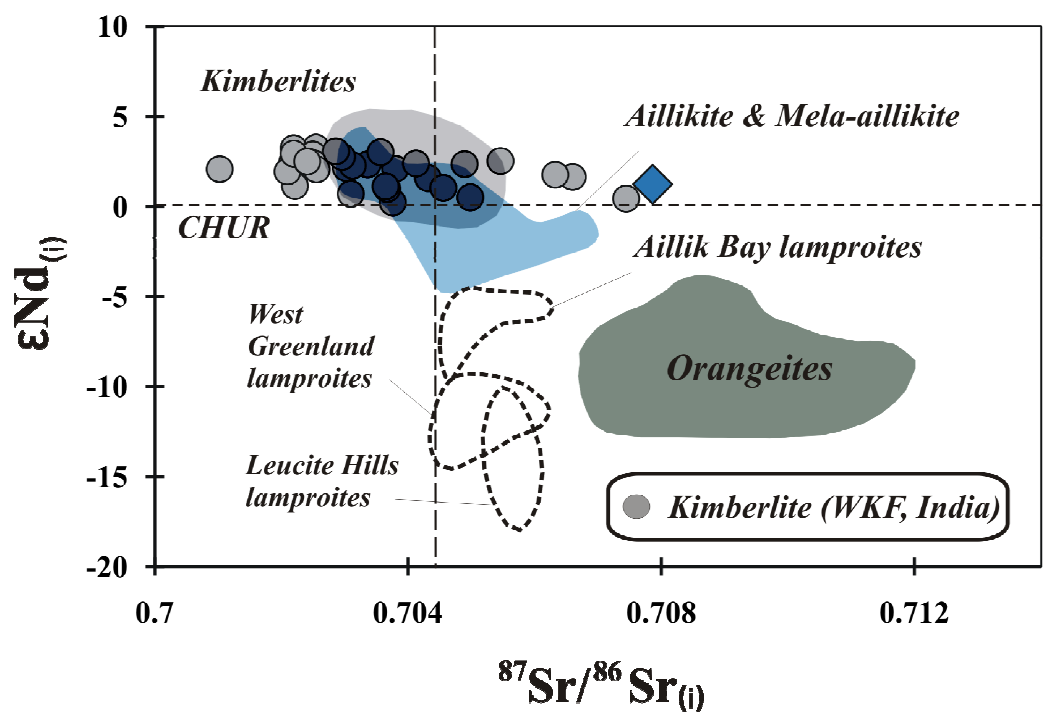

Figure 2: Initial $\varepsilon N d v s{ }^{87} \mathrm{Sr} /{ }^{86} \mathrm{Sr}$ for aillikite under study. Compositional fields for aillikite and mela-aillikite are from Tappe et al. (2008) and references therein and from Donnelly et al. (2011). Unpublished data for Wajrakarur kimberlites, Southern India is given for comparison. 
The aillikite dyke here shows isotopically depleted nature $\left({ }^{87} \mathrm{Sr}^{86} \mathrm{Sr}_{\mathrm{i}}=0.70786\right.$ and $\left.\varepsilon \mathrm{Nd}_{\mathrm{i}}=+1.25\right)$ similar to kimberlites of WKF $\left({ }^{87} \mathrm{Sr}^{86} \mathrm{Sr}_{\mathrm{i}}=0.70102-0.70744, \varepsilon \mathrm{Nd}_{\mathrm{i}}=+0.23\right.$ to +3.28$)$. However initial ${ }^{87} \mathrm{Sr} /{ }^{86} \mathrm{Sr}$ values are on higher side and resembles upper limit of WKF kimberlties and close to recently reported aillikites from Kaapvaal craton, South Africa $\left.{ }^{87} \mathrm{Sr}^{86}{ }^{8 \mathrm{Sr}_{\mathrm{i}}}=0.70670\right)$ (Donnelly et al., 2011).

Mineralogical, geochemical data and similar isotopic compositions of aillikite reported here and synchronous kimberlites from WKF indicates its origin from same tectono-magmatic event and from similar mantle source region with a different metasomatic assemblage and also indicates magma generation in the presence of $\mathrm{CO}_{2}$ like those in the case of kimberlites.

\section{References}

Becker M, Le Roex AP (2006) Geochemistry of South African on and off craton Group I and II kimberlites: petrogenesis and source region evaluation. J Pet 47: 673-703

Chalapathi Rao NV, Dongre A, Wu FY, Lehmann B (2016) A Late Cretaceous (ca. 90 Ma) kimberlite event in southern India: Implication for sub-continental lithospheric mantle evolution and diamond exploration. Gond Res 35: 378-389

Chalapathi Rao NV, Wu FY, Mitchell RH, Li QL, Lehmann B (2013) Mesoproterozoic U-Pb ages, trace element and $\mathrm{Sr}-\mathrm{Nd}$ isotopic composition of perovskite from kimberlites of the Eastern Dharwar craton, southern India: Distinct mantle sources and a widespread 1.1 Ga tectonomagmatic event. Chem Geol 353: 48-64

Dongre A, Chalapathi Rao NV, Viljoen KS, Lehmann B (2017) Petrology, genesis and geodynamic implication of the Mesoproterozoic-Late Cretaceous Timmasamudram kimberlite cluster, Wajrakarur field, Eastern Dharwar Craton, southern India. Geosci Front 8 (3): 541-553

Donnelly CL, Griffin WL, O'Reilly SY, Pearson NJ, Shee SR (2011) The kimberlites and related rocks of the Kuruman kimberlite Province, Kaapvaal craton, South Africa. Contrib Min Petrol 161: 351-371

Mitchell RH (1986) Kimberlites: Mineralogy, geochemistry and petrology. New York: Plenum

Tappe S, Foley SF, Jenner GA, Kjarsgaard BA (2005) Integrating ultramafic lamprophyres into the IUGS classification of igneous rocks: Rationale and implications. J Petrol 46: 1890-1900

Tappe S, Foley SF, Jenner GA, Heaman LM, Kjarsgaard BA, Romer RL, Stracke A, Joyce N, Hoefs J (2006) Genesis of ultramafic lamprophyres and carbonatites at Aillik Bay, Labrador: a consequence of incipient lithospheric thinning beneath the North Atlantic craton. J Petrol 47: 1261-1315

Tappe S, Foley SF, Kjarsgaard BA, Romer RL, Heaman LM, Starcke A, Jenner GA (2008) Between carbonatite and lamproite- Diamondiferrous Torngat ultramafic lamprophyres formed by carbonate fluxed melting of cratonic MARID type metasomes. Geochim Cosmochim Acta 72: 3258-3286 